\title{
The heritage sewer networks of Kolkata (Calcutta) and ascertaining their coping potential under growing urban pressures
}

\section{Sunil Kumar Murmu, Nazimul Islam \& Dhrubajyoti Sen}

To cite this article: Sunil Kumar Murmu, Nazimul Islam \& Dhrubajyoti Sen (2021): The heritage sewer networks of Kolkata (Calcutta) and ascertaining their coping potential under growing urban pressures, ISH Journal of Hydraulic Engineering, DOI: 10.1080/09715010.2020.1870173

To link to this article: https://doi.org/10.1080/09715010.2020.1870173

\section{央 Published online: 03 Jan 2021.}

Submit your article to this journal

\section{山 Article views: 14}

\section{Q View related articles $\asymp$}

\section{View Crossmark data ¿}




\title{
The heritage sewer networks of Kolkata (Calcutta) and ascertaining their coping potential under growing urban pressures
}

\author{
Sunil Kumar Murmu ${ }^{a}$, Nazimul Islam iD ${ }^{b}$ and Dhrubajyoti Sen ${ }^{c}$ \\ aDepartment of Civil Engineering, National Institute of Technology, Patna, India; 'bnstitute of Earth Surface Dynamics, University of Lausanne, \\ Lausanne, Switzerland; 'Department of Civil Engineering, Indian Institute of Technology Kharagpur, Kharagpur, India
}

\begin{abstract}
The earliest sewer networks of the city of Kolkata, or erstwhile Calcutta, covered a modest $19.1 \mathrm{~km}^{2}$ of the central district of the city and the first phase of the network-commenced operation in 1868 . Calcutta, then, was the capital of imperial India under British rule and the combined sewer was only second in the empire after London. The conduits of this sewered catchment, and of the two others that followed subsequently, continue to be in operation despite heightened base flows due to population rise and increased stormwater runoff because of greater imperviousness arising from urbanisation. The recent lining of the sewer conduits or augmentation of the drainage pumping capacities has not, however, reduced street waterlogging during the monsoons by a great amount. One aim of this study is to investigate the reasons behind this failure of the system and evaluate the sustainability of these historic sewers with the help of mathematical models, verifying them as far as possible with the scant available data. The other objective is to make the reader aware of the engineering heritage of the country and document the available information about the Calcutta sewer networks for providing a base of reference for future researchers.
\end{abstract}

\section{ARTICLE HISTORY}

Received 28 June 2020

Accepted 26 December 2020

\section{KEYWORDS}

Hydraulics; sewers and

drains; mathematical

modelling; SWMM;

LISFLOOD-FP

\section{The heritage sewers: a brief historical introduction}

The history of scientific sewerage and drainage in India may be traced back to the period of British domination of the subcontinent. The combined sewage and runoff disposal system at Kolkata, or erstwhile Calcutta, is the oldest to be planned, designed, and constructed by British engineers in the country. The city of Kolkata is located on the eastern bank of river Hooghly, which is one of the distributaries of river Ganges in its delta and about a hundred kilometres upstream from the sea and happens to be the first and the only riverine port of the country (Gardner. et al. 2020). Recently, the city observed the sesquicentennial year of establishment of India's first centralised underground combined sewerage infrastructure. Figure 1 provides a location map of the city, indicating the three early sewered urban drainage areas (Town, Suburban, and Maniktala) and one latter addition (T. P. Basin, which is consists of mostly open drains), which drain most of the sewage and runoff from the city's core areas. An outstanding example of Victorian engineering, the sewered schemes resulted from a long debate amongst engineers and planners of the era, originating from a proposal by the then Governor-General Lord Wellesley in 1803 (Dey 2015; Dey and Downey 2020). The plan that finally got sanctioned was the one by the first engineer of the Calcutta Municipal Corporation and an inventor in his own right, William Clark, in 1859. The first network, called the Town System (Figure 2), was planned to serve $19.1 \mathrm{~km}^{2}$ covering the administrative districts and a section of the city's European settlement. The combined sewers were designed for runoff resulting from a rainfall of a quarter of an inch per hour $\left(\sim 6.35 \mathrm{~mm} \mathrm{~h}^{-1}\right)$ apart from the base flow of the city's municipal wastewater. The trunk conduit, which was designed to convey 6900 cusec $\left(\sim 195 \mathrm{~m}^{3} \mathrm{~s}^{-1}\right)$, and a section of this initial network was put into service in 1868 while the complete project was ready by 1875 (Goode 1916). A combined sewerage and drainage system of its scale was preceded only by that of London, within the British Empire. The main outfall drain, a $5 \mathrm{~m}$ by $4 \mathrm{~m}$ underground vaulted brickwork conduit, terminated at the Palmer's Bridge pumping station (marked ' $\mathrm{X}$ ' in Figure 2) on the eastern fringes of what was the city's limit at that time. From here, steampowered pumps - later replaced by electrical machines in the twentieth century - discharged to the tidal creek of Bidyadhari, about $15 \mathrm{~km}$ to the east, through open channels. Gangopadhyay and Patra (2019) may be referred to for details about the Bidyadhari creek and others neighbouring channels the eastern fringes of Kolkata which slope in a general south-eastward direction and finally debouch into the sea. Unlike the London sewer lines outfalling to the neighbouring Thames, this sewer network and the subsequent two that were laid in Kolkata drain away from the river Hooghly, due to higher banks and natural levees along the river. In fact, the city's land surface gently slopes from the river to the east. A technical weakness of the sewer system, however, was the decision to connect the conduits and branches at their inverts, the ill effects of which started showing up shortly after the system was put into operation (Goode 1916).

In keeping with the general practice of the times, there was no provision for any formal treatment of the sewage, but records indicate that the wastewater canal conveying the discharges from the pumping station widened out to a large settling basin before outfalling to the Bidyadhari, and the settled sludge was manually cleaned periodically. The Town System comprised around $60 \mathrm{~km}$ of main brick sewers and $240 \mathrm{~km}$ of stoneware pipe sewers. Interestingly, though the 


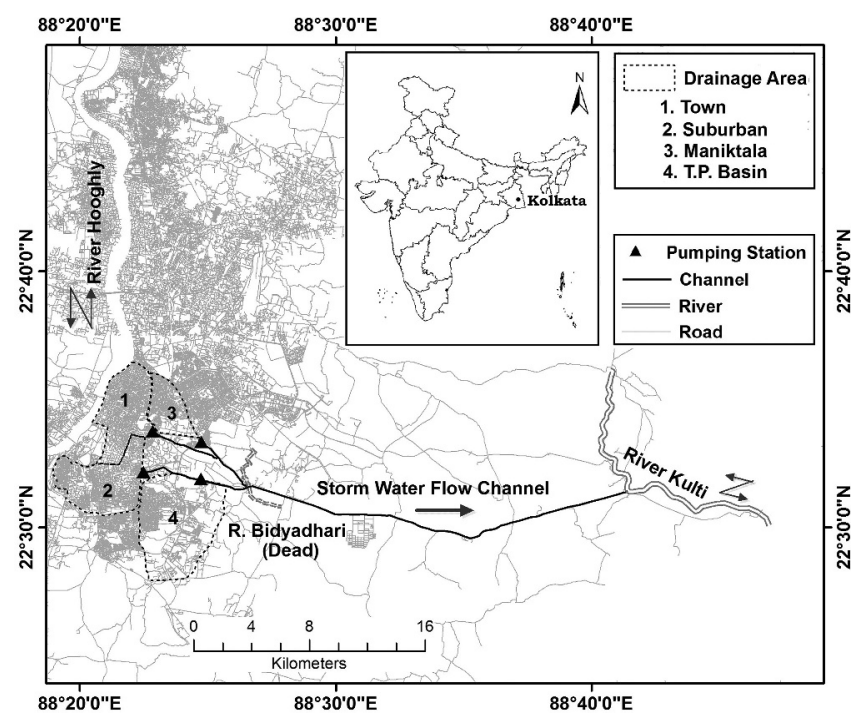

Figure 1. Kolkata (Calcutta), on the banks of river Hooghly, showing the three sewered sewerage and drainage catchments and one unsewered catchment with outfall channel running eastward. Inset: Location of the city of Kolkata within India.

main sewer lines of this system sloped away from river Hooghly to the Bidyadhari on the east, connections to Hooghly through sluices could allow water into the conduits at high tides by gravity, for providing flushing doses and keeping the lines silt free (Dey 2015; Dey and Downey 2020).

The next sewer network to be laid in the city was the 'Suburban System' which, as the name suggests, helped to drain the then semi-urban peripheral areas of the city. Covering an area of around $25.7 \mathrm{~km}^{2}$, the conduit network of this catchment terminated at the pumping station marked $\mathrm{Y}$ in Figure 2. A head cut channel further conveyed the

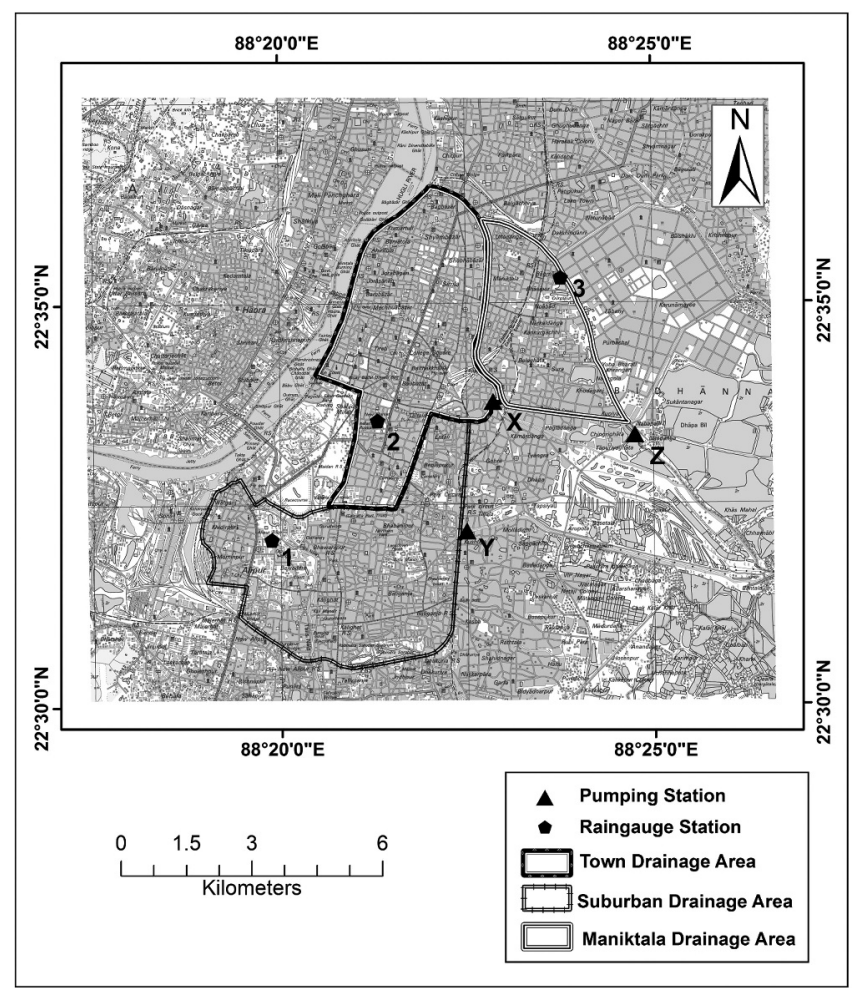

Figure 2. A closer view of the three combined sewerage and drainage catchments of Kolkata, referred to as the heritage networks in this work, along with the location of the terminal pumping stations. The locations of the rain gauges used in the study are also shown. effluents to the Bidyadhari. This pumping station, commissioned by the late nineteenth century, comprised of around $30 \mathrm{~km}$ of main masonry sewer and $35 \mathrm{~km}$ of stoneware pipe sewers (Goode 1916). At inception, therefore, the suburban catchment, though spread over a larger area than that of the town, contained shorter mains and fewer branch pipes. Subsequent augmentation of pumps was carried out, keeping pace with the urbanisation taking place in the city over the first quarter of the twentieth century.

Unfortunately, by 1930-s the tidal creek of Bidyadhari was declared as unusable, being choked with silt from the discharges brought in by the two sewerage systems. Efforts initiated thereafter to find an alternate solution for disposing the city's wastewater and runoff culminated in a proposal of extending the drainage channels further about $35 \mathrm{~km}$ east to another tidal creek - the Kulti. Provisions were made to convey discharges from the pumping stations in two separate channels - a deeper and wider stormwater flow canal and a smaller and slightly elevated - dry weather flow channel which is in use till today. The latter, conveying mostly municipal wastewater, is operated mostly during the non-monsoon seasons, spanning for about 8 months a year. A part of the flow is diverted to the fishery lagoons of the East Kolkata Wetlands (Dasgupta 2019), which were saltwater swamps connected to the river Bidyadhari, but have since been converted to shallow fish farming lagoons (Bose 1944) with a thriving pisciculture practice (Saha et al. 2016). The lakes act as stabilisation ponds and wastewater remediation systems, probably the only one of its kind globally on such a large scale (Ghosh and Sen 1987; Sarkar et al. 2009). The distinctive ecology flourishing around the waterbodies has also earned it a Ramsar site recognition (Hettiarachchi et al. 2015).

The last combined drainage system built during the colonial era - the Maniktala network, comprising the areas to the east of the Town System, came up in the 1940-s. Originally a low-lying peri-urban neighbourhood, the Maniktala drainage area soon came to be grossly populated by the influx of refugees streaming in from the newly formed East Pakistan (presently Bangladesh) after the partition and independence of India in 1947. The need to evacuate the surface runoff through pumps from this locality quickly became imminent, leading to the commissioning of the terminal pumping station at Dhapa Lock in 1958. The Maniktala System, having a catchment of around $8.9 \mathrm{~km}^{2}$, augments the city's core drainage network and along with the other two provides interesting examples of municipal engineering executed over different phases through the past 150 years. It is important to realize that though the combined discharges of the pumping stations are conveyed through open drainage channels leading to the creeks, the sewer outflows which empty into sumps at the pumping stations are not directly affected by the tides of the oceans. This is because the pumps which lift water from the sumps for discharging into the channels try to maintain low sump levels, as far as possible, such that the sewers are not affected by backflow. However, on occasions of extreme tides, the drainage channels have been heavily affected by tidal backflows and the pumps have failed in maintaining the low sump-level conditions. Further details about the engineering and hydraulic features of the systems may be found in Basu et al (2013a, 2013b, 2014).

These vital infrastructural assets, oblivious to public view, have served the city well, but have increasingly been 
subjected to the stresses of a burgeoning population and consequent urbanisation as discussed in the following section.

\section{Demographic pressure and urbanisation impacts on the sewer networks of Kolkata}

The first systematic record of population survey for the city of Kolkata according to its distribution in the Municipal Wards of the city is obtained from the 1961 census (Haque 2013). It is inferred that the average population densities of the Town, Suburban, and Maniktala drainage areas had, respectively, been around 70,000, 40,000, and 32,500 persons per square kilometre. By 2011, the population densities had changed to about 62000,34500 , and 42000 persons per square kilometre, respectively. Although the sewers of Kolkata date back to a period when no authenticated population data were recorded, Census India (2011) data have a section on historic figures which indicates that the overall population of the city in 1901 had been around a quarter of that in 1961. Haque's study also concludes that areas covered by grass and trees in Kolkata, respectively, have reduced from about 38 and $21 \%$ in 1973 to 8 and $12 \%$ in 2010. Built-up area appears to have substantially increased during the four decades to about $75 \%$, though Bhatta (2009) suggests a figure of $85 \%$. Again, old settlement maps appear to suggest that in the late nineteenth century, the open spaces and waterbodies in the city covered as much as 50 to $60 \%$ of the total area, with the Town catchment having higher built-up area percentage compared to the Suburban basin. Thus, under pressure from anthropogenic drivers, the combined sewerage system for Kolkata has continued getting stressed over the decades, primarily for the following reasons:

(1)Increased municipal wastewater discharges proportional to the rise in population, resulting in high base flows for the sewers, and

(2)Increased imperviousness of open space from surfaces, leading to greater runoffs.

As a result, the increased combined flows often exceed the carrying capacity of the conduits, the sizes of which have remained unchanged over the years. Occurrence of street water-logging thus has also increased, apparently. The high rainfall event of 1978 (total daily precipitations of 103, 327, and $124 \mathrm{~mm}$, respectively, on 26, 27, and 28 September) had been particularly painful when the stagnated water took more than a day to subside due to the autumn tides restricting the discharges at the outfalls. The intense rainfall of 19 September 2000 also caused widespread flooding in the city. Although renovation of the underground conduits has included clearing the main sewers of solid deposits and lining them with glass-reinforced plastic (GRP) sheaths (Basu et al. 2014), they have not been modified in size or shape. The project aimed primarily at preventing further damage to the original brickwork that was caving in at places while attempting to clean them of the century-old grit. Of course, the linings have helped in making the conduits smoother with increased conveyance capacities.

\section{Evaluating the sustainability of the heritage sewers using computational models}

As shown above, the sewer networks of Kolkata, though planned and executed more than 150 years ago, have been serving the city uninterrupted despite the continuously changing built-environment. The present work, therefore, aims at investigating the adequacy of the carrying capacities of the three early sewer networks of the city (the Town, Suburban, and Maniktala drainage basins) in relieving the city streets of flooding at times of heavy rainfall now and in future. For this purpose, the Storm Water Management Model SWMM (Rossman 2015), a public domain simulation package for modelling flows through sewer networks, has been used to compute overland runoff and conduit flows. Surcharges resulting from excess runoff are linked as point sources to the twodimensional surface flow simulation code LISFLOOD-FP (Bates and De Roo 2000) for modelling over-ground inundation. This model simulates the movement of the water overflowing from the sewers which initially accumulate on the streets in the low-lying pockets of the city. Increasing discharges cause the inundation depths to rise above the kerb height or building plinths, thus overflowing into the basements and ground floors of the houses in the locality.

The LISFLOOD-FP model is a raster cell-based twodimensional surface flow simulation code working on the principles of storage cells, neglecting inertia of the moving water (that is, the momentum equations are used in their simplified form). This model is chosen here because of three primary reasons. First, the computations by the model, because of the simplified equations, are quicker in comparison to the full two-dimensional models. Second, the assumptions on which the model is developed may not involve large errors for Kolkata as the city has a very flat terrain and the flooding is due mostly to the accumulation of water within local depressions on the surface from overflowing manholes. The velocities are consequently negligible and thus are the momentum (inertia) terms. The exchange of flows between a cell and its four immediate neighbours is approximated by the Manning's relation (Bates and De Roo 2000), the difference of water levels between each pair of cells being used to compute the slope in the equation. The final reason for implementing LISFLOOD-FP is the availability of its source code from the developer of the model, Prof. Paul D. Bates of the University of Bristol, under an academic partnership program. Other two-dimensional codes presently in use worldwide are either proprietary or commercial, with limited or no public access to their source codes. However, access to the source code is essential here as the two-dimensional flow simulation model (LISFLOOD-FP, in the present case) is coupled with the output of SWMM using an interfacing code which, for the simulations described in this paper, was developed with the help of 'batch-files' in the MS-DOS environment using the 'command line' arguments. These files were also used to fetch data from the repository of rainfall values and, although not used for the present work, may be configured for receiving data during real-time inundation predictions when rainfall information is received continuously with time and the file storing this data is updated dynamically.

For the present simulations, no adjustment has been made for building footprints within the urban drainage catchments since almost invariably the floodwater from the streets finds a freeway to the basements or ground floors of most buildings. The residents, having adapted themselves to these recurrent inundations, permit such incidences which 
rarely exceed a metre and subside normally within a couple of hours.

\section{Data availability}

In the absence of an official elevation dataset for the city, a 'Total-Station' survey was carried out along some of the major streets within the three sewerage drainage network catchments with the financial assistance received from the computer company IBM Ltd. under their Centennial Grant in 2011. Details about this grant and the works carried out with the support, including the setting up of the real-time digital rainfall data collection network for Kolkata, may be obtained from Sen (2013). The dataset of spot levels was interpolated to generate a digital elevation model (DEM) of $50 \mathrm{~m}$ grid size. The elevation range for the three catchments (about $53.7 \mathrm{~km}^{2}$ ) varies between $3 \mathrm{~m}$ and $4 \mathrm{~m}$ above mean sea level (MSL), with the land sloping gently towards the east. The terrain essentially is flat with local pockets of depression. The sections of the conduits, topology of the sewer networks and location of the manholes were obtained from the report of World Bank (2001).

The sewer-flow model, SWMM, was initially calibrated to obtain an optimum roughness value of the conduits. As a guideline, the values indicated in standard references were chosen initially and then adjusted by matching the computed and measured outflow discharges at the pumping stations for past around 10 years. The hourly outflow discharges at the pumping stations were facilitated by accessing the log books maintained at each station and noting the running hours of the different pumps located at the station for different years. Then, by multiplying by the pumps' respective discharging capacities and summing up, the hourly values of the total discharge from a pumping station were obtained. For validating the sewer-flow model, the time-history of the point rainfall values recorded at specific stations across the city and the corresponding outflow discharges from the terminal pumping stations were selected for two specific time periods (for the monsoon months of the years 2013 and 2015). The rainfall data obtained from the network of digital rainfall monitoring system are transmitted in real-time at intervals of 15 minutes (Sen 2013) and was used as inputs to drive the model SWMM. Sump water levels at the pumping stations are also digitally recorded by a similar network and transmitted at the same frequency. These values were used as the downstream condition of the outflowing sewers in SWMM. Of course, it was observed that the sump levels remained low for these 2 years, indicating no significant tidal influence. Hence, backflow was not an influencing factor for the sewer outlets during the simulations of the validation phase.

There is no direct record of surface-inundation depths or water-logging extents though a street water level monitoring sensor has been installed at a specific location of the city, on an experimental basis, in 2019 with the financial assistance of the Kolkata Municipal Corporation. The city traffic police force, however, also gathers approximate information on water-accumulation at important street junctions and uploads these on the social media platform 'Facebook', for the benefit of the public. Collated from the information provided by the traffic constables on duty, these flooding reports categorise the water accumulated in qualitative terms, such as hip, knee, and ankle deep which are uploaded to the webpage frequently. In the absence of any other reliable source of measurement of water inundation in the city, the information posted by the police is used in the present study by converting them to numerically equivalent values, like, $1.0 \mathrm{~m}, 0.5 \mathrm{~m}$, and $0.1 \mathrm{~m}$, respectively, and made use for gauging the street inundations.

For evaluation of future scenarios, statistical analyses of rainfall intensities were carried out using hourly rainfall data (1980 to 2015) recorded by the India Meteorological Department (IMD) at their Alipore and Dumdum stations of the city. The analyses carried out with these data are described in greater detail in Section 6.

\section{Setup and validation of the models for sewer flow and overland inundation simulation}

The numerical models SWMM and LISFLOOD-FP were setup for the three urban catchments for simulating, respectively, the flow through the sewer networks and flooding on the ground surface resulting from sewer surcharges. The three catchments defined in SWMM, that is, Town, Suburban, and Maniktala, were each linked to a unique rain gauge of the digital network, depending upon its proximity to the gauge. Within each catchment, sub-catchments are defined around the manhole locations, which are assumed to be the outlet-points of the runoff generated from the sub-catchments and leading to the underground sewer network. The sewer overflows computed by SWMM at each manhole location, and at every computational time step, are introduced into LISFLOOD-FP as point discharges, permitting the latter to estimate the possible extent of flooding at the given time. The computational time step for both the models is set to 5 minutes but the output data are reported at intervals of 15 minutes, matching with the data transmission rate of the rain gauge network. A one-directional coupling methodology is used in the present case, in which only the excess surcharges from the sewers are assumed to overflow onto the surface, without reintroducing it back into SWMM. Apparently, this methodology may look erroneous at a first glance but it may be remembered that SWMM, independently, keeps a record of the expelled volume of water at each manhole node at any given point of time, assuming it to be temporarily stored in imaginary containers above the street level. When the runoff and, consequently, the sewer flows reduce, SWMM automatically withdraws the stored surcharges into the conduits. Hence, SWMM works independently of LISFLOOD-FP, which only reads the computed surcharged volumes at the different nodes at any given point of time from the temporary output files generated by SWMM, and uses these to estimate the area inundated over the ground surface. Since SWMM runs independently of LISFLOOP-FP (there is no volumetric feedback from LISFLOOP-FP into SWMM), the mass-balance checks in SWMM also remain unaffected during the simulations. However, fetching the surcharge data computed by SWMM at any time by the LISFLOOD-FP model is facilitated by an intermediate code that repeats at every computational time step. This code is activated through a batch-file using the MS-DOS commands, quite similar to the codes used for fetching the rainfall values from the data repository for running the SWMM model.

It may be emphasized that the rainfall data are applied only to SWMM, and not to LISFLOOD-FP. The SWMM model converts the rainfall intensity into discharge with the 
help of simplified catchment flow equations and applies the discharge rates at the specified junction nodes of the network through the manhole connections. Although LISFLOOD-FP too has the provision to accept rainfall data, converting it to discharge by multiplying by the area of the computational grid cell, this is not done here in order to avoid doublecounting of the rainfall-induced runoff which will result in an overestimation of the inundation area.

Further details on the implementation of the SWMM and LISFLOOP-FP models are presented in the following sections. For theoretical and computational details, Rossman (2015) and Bates and De Roo (2000), respectively, may be referred to.

\subsection{Implementing the sewer network flow model, SWMM}

The SWMM model approximates the discharges through the sewer conduits as one-dimensional-free surface or pressurised flows (depending upon the prevalent conditions) and uses the equations of continuity and momentum in one-dimension to model the flow variables. Of the different options available, the full momentum equation is employed here to account for any possible backflow effects within the conveyance elements. An average impervious area factor of $85 \%$ is chosen for the urban sub-catchments based upon the estimates of Bhatta (2009), Haque (2013) and Mukherjee et al. (2018). The Manning's roughness coefficient for the conduits is assigned a value of 0.01 , which agrees with the calibration results, and also typifies conduits having PVC finished linings.

To initiate the computations in SWMM, steady-state base flows commensurate with the catchments' municipal discharges, are specified in all the branches of the network. In the absence of observed values of the base flows, approximate figures, obtained through estimates based upon population numbers, are applied to the different branches of the networks. The computations for conduit flow thus commence from non-pressurised conditions but a greater volume of runoff due to rainfall, as during continuous events of a heavy shower, may cause some pipes to transit to pressurised flows. Sufficiently high runoff may cause some of the manholes to surcharge. As mentioned above, SWMM does not eliminate the water overflowing the manholes from the system but assumes them to be stored temporarily in hypothetical bins only to be fed back once the rain subsides. The expelled volume from each overflowing manhole is recorded at each time step and passed on by an intermediate code to the overland flow model LISFLOOD-FP as point source values at appropriate spatial locations.

SWMM, being a flow routing model, also requires an outlet boundary condition to be specified. Since the main sewers in all the three drainage systems drain into sumps from where the water is evacuated by the pumps and discharged into open drains, the sump water levels were applied as the desired input. During the validation of the model, it was observed that the pumps were able to keep the sump water levels sufficiently low without any backflow effect in the sewers. Hence, in all the simulations presented in this study, a free outfall condition is specified at the outlet end of the sewer networks.

\subsection{Implementing the overland flow model, LISFLOOD- FP}

The LISFLOOD-FP model, as discussed, is a raster cell-based two-dimensional surface flow simulation code that works on a raster (square) grid of spatial discretization. The computational cell size in the present case is chosen as $50 \mathrm{~m}$, corresponding to the pixel size of the DEM. With this size of the cells, the results on a desktop PC are computed within a reasonable time (around 1-minute clock-time required for each time step of calculation). The complete simulation exercise is carried out by advancing in time through increments of computational time step till the end of the simulation period. The sourcing of data from the temporary result file of the SWMM model as input to the LISFLOOD-FP model is conducted once every time step.

\subsection{Validating the computed sewer flows and surface inundations}

The simulated sewer outflows computed by SWMM for Town, Suburban, and Maniktala catchments are compared with the observed discharges at the respective basin outlets at Palmer's Bridge Pumping Station (PBPS), Ballygunge Drainage Pumping Station (BDPS), and Dhapa Lock Pumping Station (DLPS), respectively.

Two rainfall events, one each from the years 2013 and 2015, are chosen for the validation exercises. These years have been among the wettest in recent times. The 15-minute rainfall data from the digital stations of Alipore, New Market and Ultadanga (locations 1, 2 and 3 in Figure 2 respectively) are used as input for the SWMM model. The hyetographs for Alipore are shown in Figure 3 for the events of the 2 years.
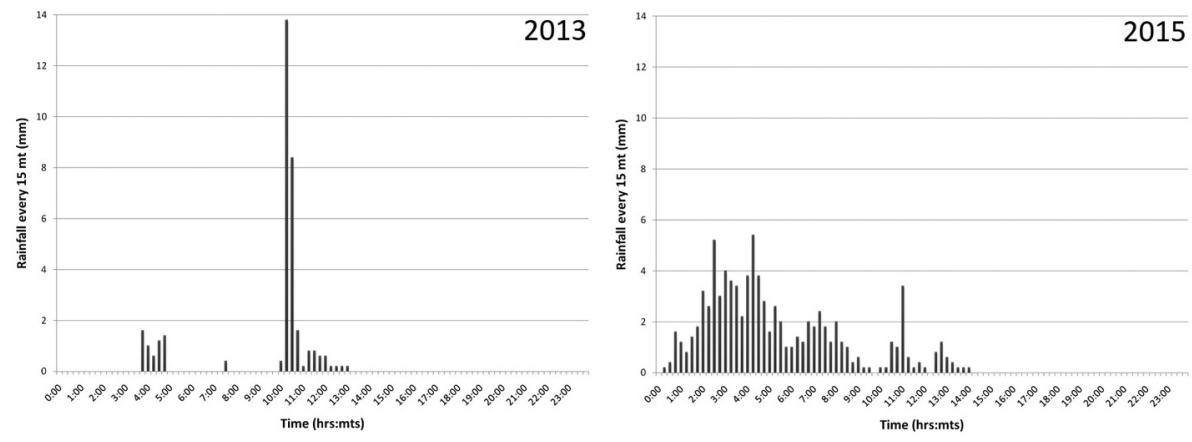

Figure 3. Hyetographs of the rain for: (a) 2 September 2013; (b) 1 August 2015 from the digital rain gauge located at the premises of the India Meteorological Department weather observatory at Alipore, Kolkata. 

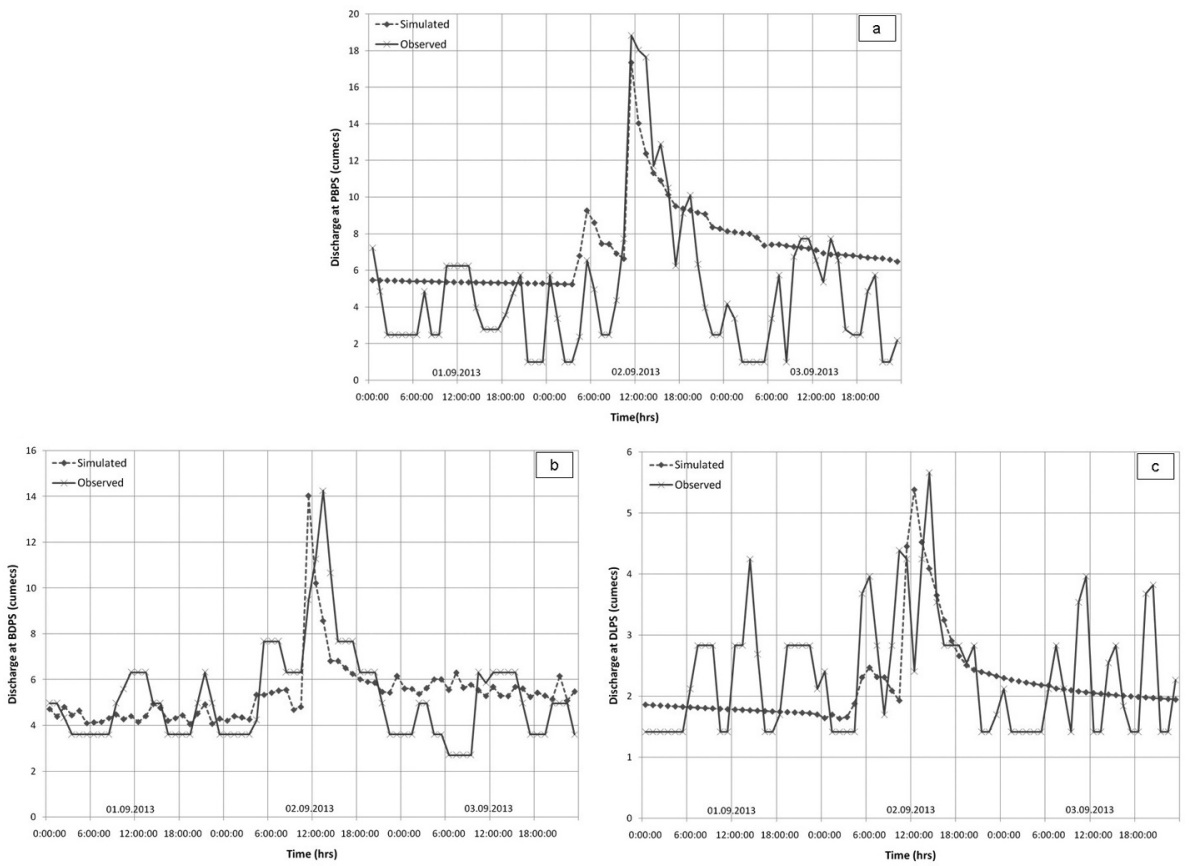

Figure 4. Simulated and observed discharges for the 2013 event: (a) Palmer Bridge Pumping Station (PBPS); (b) Ballygunge Drainage Pumping Station (BDPS); (c) Dhapa Lock Pumping Station (DLPS).

The 2013 event was a short, intense burst of rainfall, while that of 2015 was of lower intensity but much prolonged.

The computed and observed outflows at the three pumping stations for the year 2013 are compared in Figure 4. The computed peak discharges occurring on the 2nd September appear to be in the same range as those observed though the discharges a day before and after do not match perfectly. One reason for the variation could be the fluctuations of the municipal wastewater flows, which serve as the base flows for the conduits but not modelled in the present work as there is no way of gauging these flows within the system. This may be considered as a limitation of the present work and the model results may be improved if the municipal discharges are also included in the model. For the rainfall event of 2015, the simulated and observed discharges at these pumping stations are shown in Figure 5. The showers had mostly been limited to the $1^{\text {st }}$ of August, with relatively dry days before and after. However, with the event being much prolonged than that of 2013, the total volume of runoff from each catchment is seen to be greater. The simulated discharges at all the three outfalls for 2015 appear to be underestimated by SWMM during the passage of the peak discharge, and the difference is much greater for 2013. However, it is also observed that for both the years (2013 and 2015), the simulated discharges beyond the peak discharge (that is, during the recession limbs) are higher than those observed. This indicates that the error may more likely be due to the simplified computations carried out by SWMM
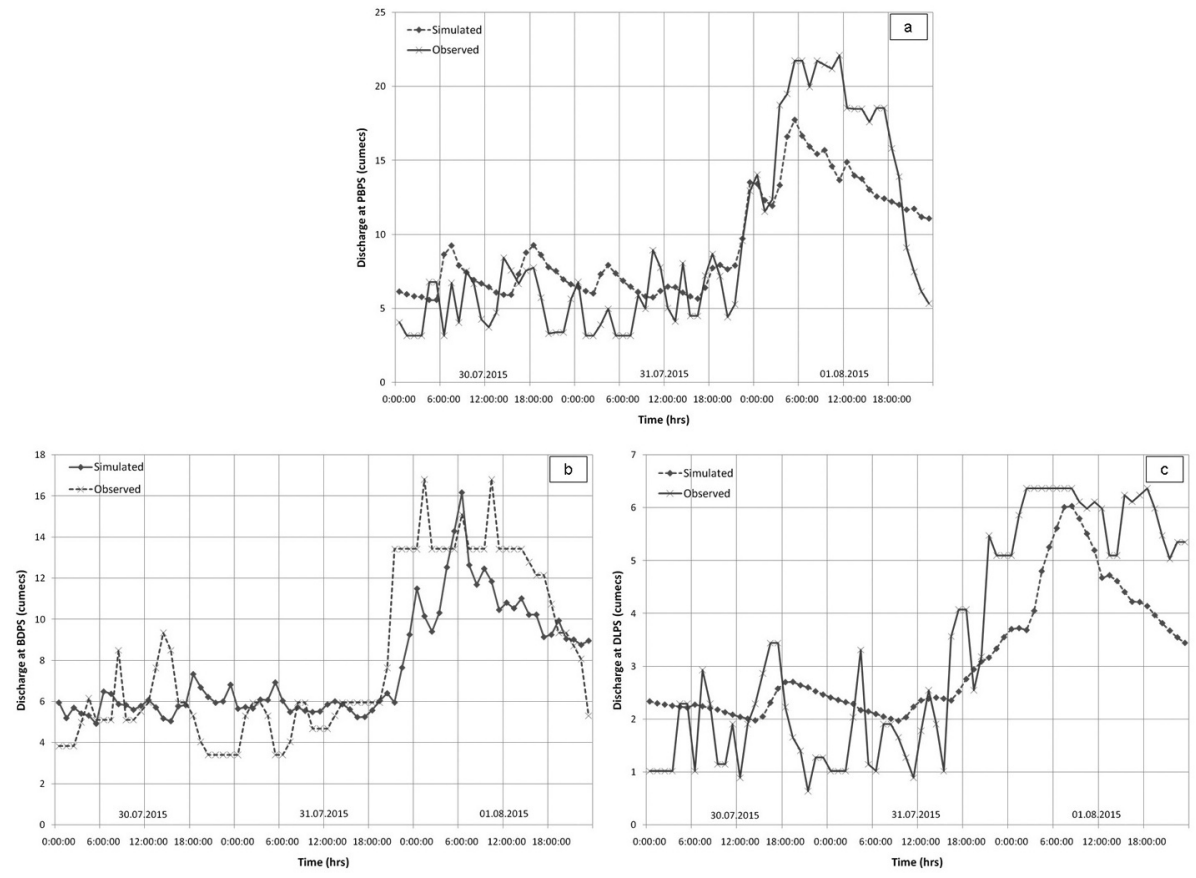

Figure 5. Simulated and observed discharges for the 2015 event: at PBPS (a); BDPS (b); and DLPS (c). 



Figure 6. Rainfall event of 2013: (a) Simulated maximum surface inundations; (b) Streets inundated as per Police report (from the only details reported at 12:30 hours).

and fluctuations in municipal discharges may not be the sole reason for the discrepancy between the simulated and observed. Specifically, SWMM appears to be estimating smaller outflow discharges during and around the peak outflows, preferring to temporarily store the excess flows (the difference between the inflows and the outflows) as surcharges at the overflowing node points. During the falling stage (post-peak), the stored water from the surcharge volumes is drained back into the system, resulting in higher values of computed flows in the recession limbs as compared to the observed flows.

The surface inundations were computed simultaneously at each time step by LISFLOOD-FP using the overflows from the manholes. Figures $6 \mathrm{a}$ and Figures $7 \mathrm{a}$ show the computed inundations for years 2013 and 2015 respectively at such times when the flood depths were maximum, which were validated with the available descriptive reports of Kolkata (Calcutta) Traffic Police after converting to numeric values and mapped ( $6 \mathrm{~b}$ and $7 \mathrm{~b}$, respectively). The validation is approximate, as the numeric conversion from descriptive is also a rough guess, as explained in Section 4 above. Although it is not possible to present the inundation results at all times, the following may be concluded, based upon the computations:

(3)The rainfall event of 2013 being short but intense, occurring for about half an hour, the corresponding high surcharges result in widespread flooding at the time of maximum inundation (Figure 6(a)) and prevails for only one computation time step of 15 minutes.
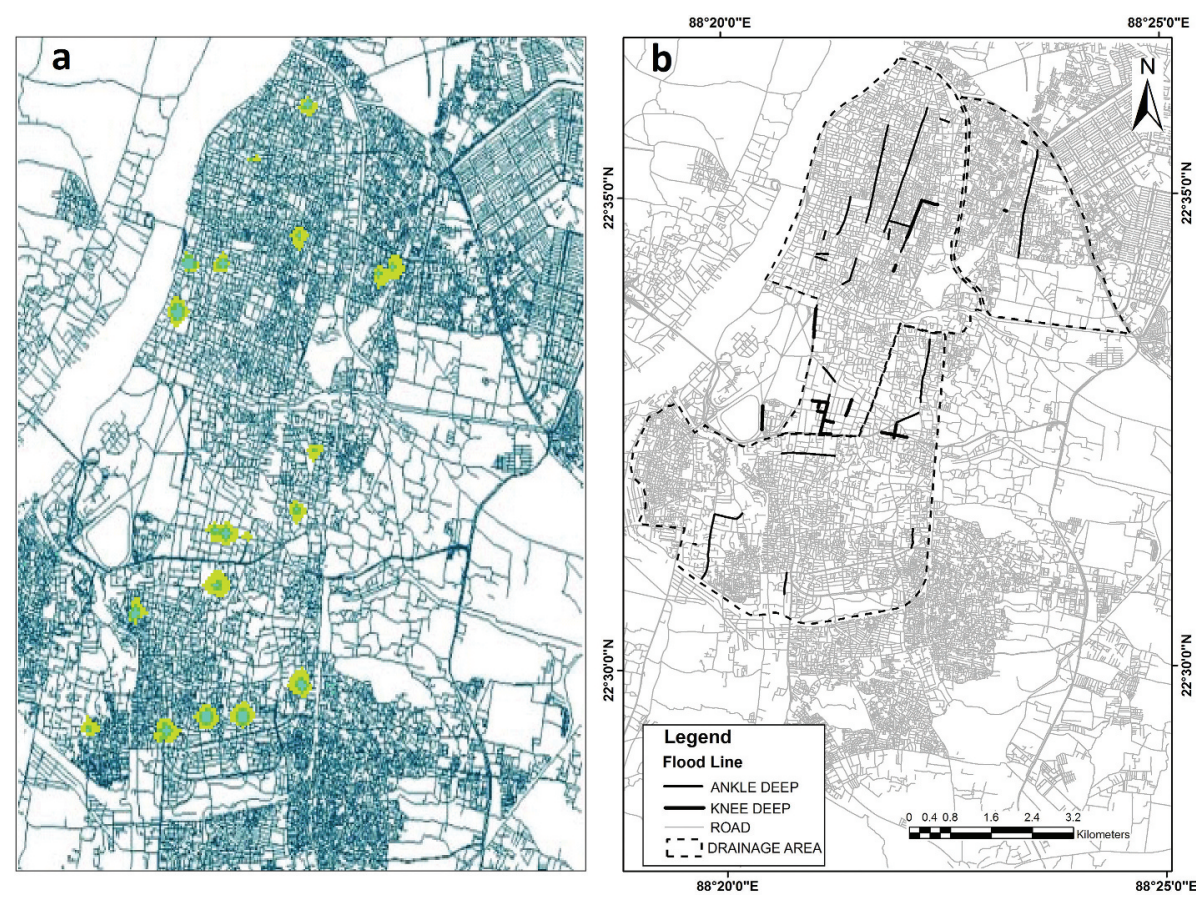

Figure 7. Rainfall event of 2015: (a) Simulated maximum surface inundations; (b) Streets inundated as per Police report (from the report of 09:00 hours). 


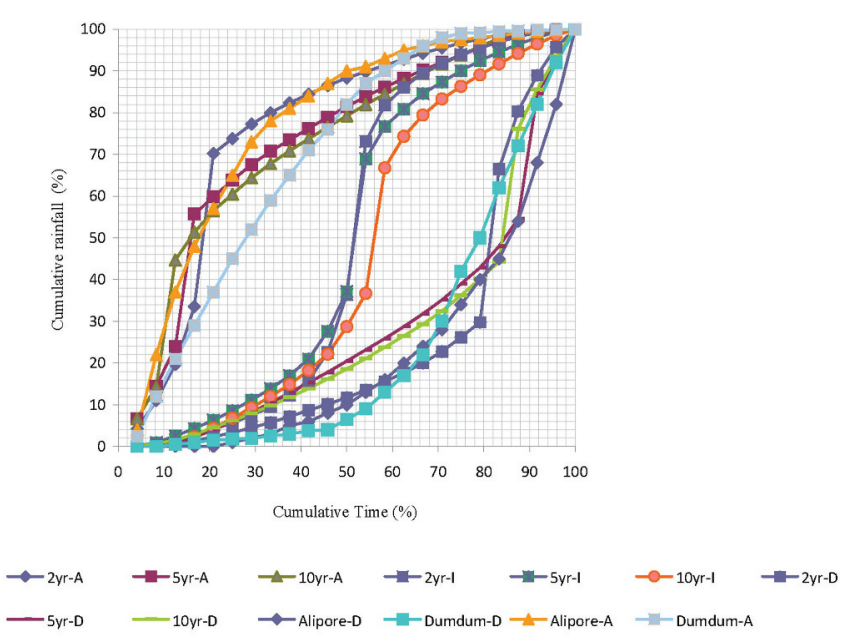

Figure 8. Rainfall time-distribution curves for Kolkata derived from hourly rainfall observations from 1978 to 2010 .

(4)The event of 2015 is more sustained and the maximum computed inundation (Figure $7(\mathrm{a})$ ), though not as widespread as in 2013 (Figure 6(a)), persists longer. This situation is more likely to cause traffic disruptions resulting from the sustained waterlogging.

Whereas, some observations of street inundations from the police reports may be summarised as:

(5)The 2013 event was reported only once: at around noontime, whereas the 2015 reports were posted more than once during the day. This confirms the fact that the inundations for 2013 had indeed been brief and those of 2015 were much prolonged, concurring with the simulations.

(6)The 2013 simulated inundation map (Figure 6(a)) shows several affected locations which are not reflected in the map recreated from police reports (6b). One possible reason for this discrepancy may perhaps be due to waterlogging at these spots prevailing only for short durations and not considered worth reporting.

\section{Assessing coping potential of the combined networks for future uncertainties}

The observations from the previous sections provide preliminary indicators for the performance of the 150 year old sewerage system under present conditions. The two storms of 2013 and 2015, having different characteristics, generate surface flooding with dissimilar temporal and spatial distributions. Apart from storm patterns, physical factors like conduit friction and pumping rates are also likely to affect flooding patterns. The recent glass-reinforced plastic (GRP) lining of the sewer conduits may have reduced the frictional resistance and the high-capacity pumps installed at pumping stations evacuate water reaching the sumps immediately, but flooding of the low pockets in Kolkata continues to recur. Apparently, the smoother conduits still retain their original cross-section and thus the increased base flows and storm runoffs reaching the sewers under the present conditions together exceed the conveyance capacities of the conduits than for which they were originally designed. Increasing the size of the conduits is not feasible, which involves the massive excavation of the streets overlying the conduits. Hence, flooding in certain pockets of Kolkata seems inevitable for a critical combination of factors, including rainfall, which is explored using the calibrated and validated simulation models SWMM and LISFLOOD-FP.

Potential climate change influences on rainfall are not considered here and the networks' performance is assessed under rainfall of varying intensities corresponding to return periods derived from past rainfall history. Observations from real events indicate that along with intensity, the time distribution of rainfall also plays a role in influencing conduit flow and inundation patterns, which are also checked.
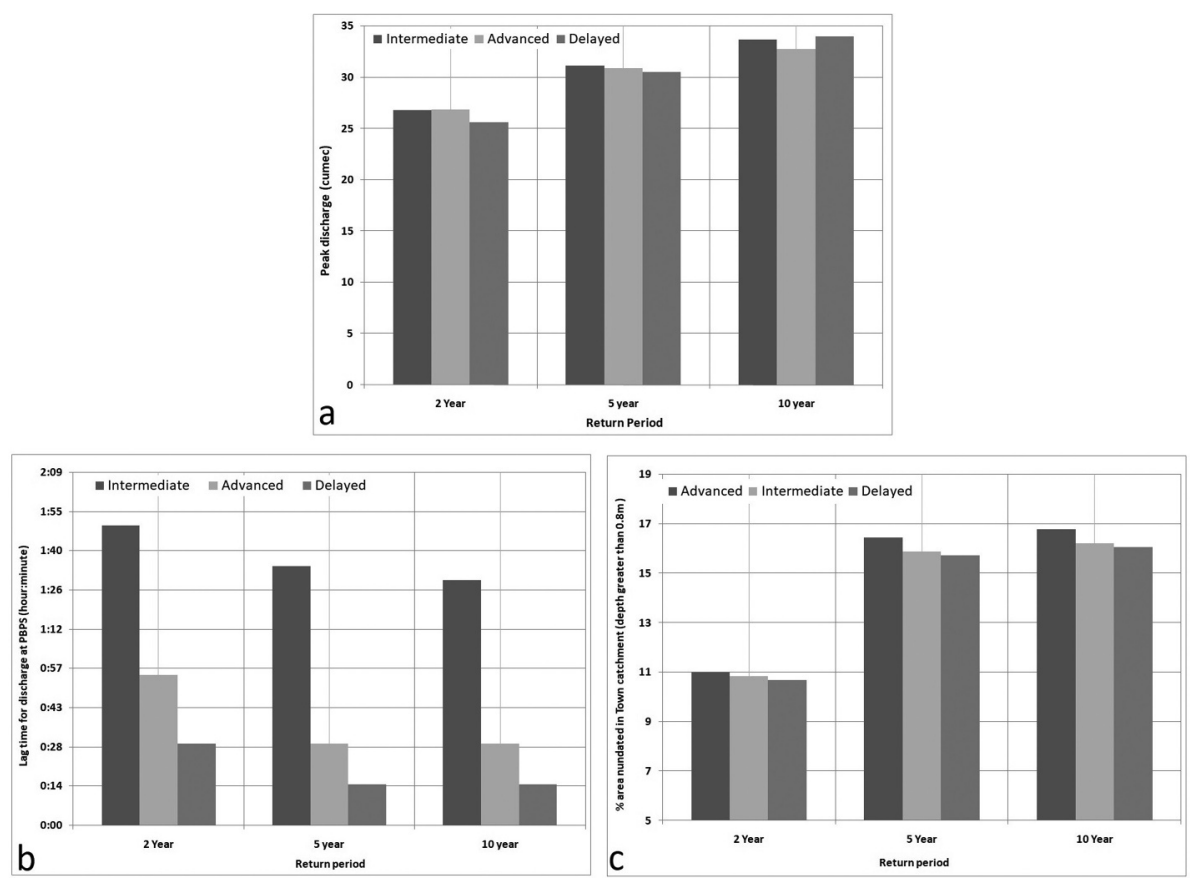

Figure 9. Maximum surcharge discharges reaching the terminal pumping station (PBPS) of the Town catchment (a); its lag time for discharge for 2, 5 and 10 years of return periods (b) and percentage area inundated at three different return periods (c). 


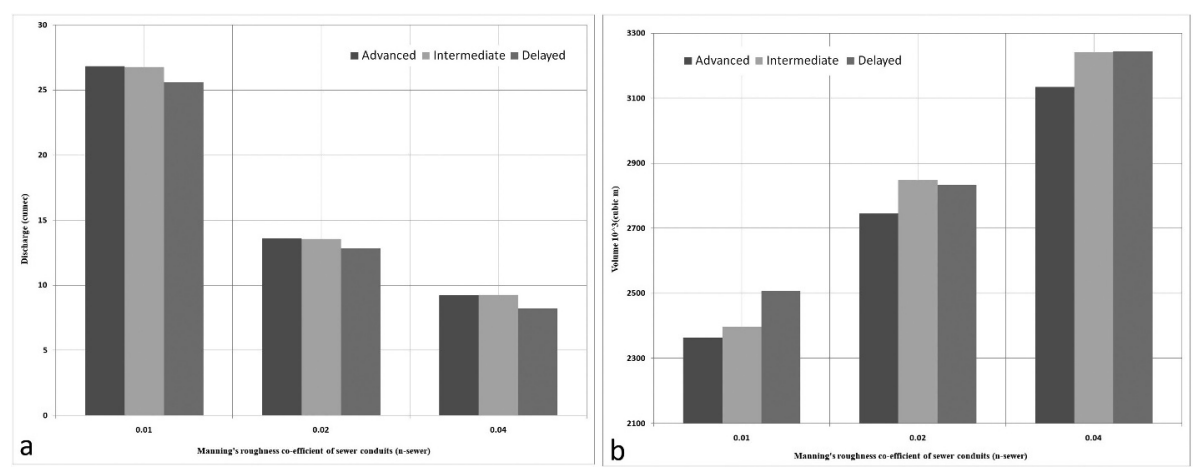

Figure 10. Peak discharges reaching the PBPS at different Manning's roughness co-efficient $(\mathrm{n})$ of sewer conduits (a) and maximum volume of water expelled to the street from the surcharge in the Town catchment (b).

Assuming the GRP linings may roughen by abrasion with time, changes in conduit friction factors are investigated along with a possible variation of ground surface friction. Assuming insufficient pumping, sump-level variations are checked to assess their influence on reduced conduit flow and the resulting increase in surface flooding.

Since the sewers form a combined system, base flows from municipal waste discharges are important and these have certainly increased over the years. However, a recent decline in population within the catchments indicates that further rise may not occur. Similarly, although the proportion of paved surface in the region has increased considerably over the past 100 years, any further rise appears unlikely and the surface runoff conversion rate from rainfall is expected to remain unchanged in the future. Hence, these two factors are not varied in the parametric studies demonstrated in the following sections.

\subsection{Rainfall intensity and time distribution}

The hourly rainfall data for the years 1980 to 2014 of the India Meteorological Department (IMD) operated meteorological stations in the city, Alipore and Dumdum are used to develop: (i) intensity-duration-frequency relations, and (ii) cumulative rainfall time-distribution curves (Figure 8). The 35-year records from the two stations indicate slightly higher rainfall intensities for Alipore station, are thus used to generate hypothetical rainfall hyetographs for 2,5 , and 10 -year return periods by the alternating block method (Chow et al. 1988), referred here as the intermediate distribution. The resulting hypothetical hyetograph corresponds to the 'normal' distribution of rainfall intensifies during a storm (curves $2 \mathrm{yr}-\mathrm{I}, 5 \mathrm{yr}-\mathrm{I}$, and $10 \mathrm{yr}$-I in Figure 8 ). The hourly rainfall series for 6 hours or longer events recorded at Alipore and Dumdum for the 35 years are used in preparing cumulative rainfall time-distribution curves to find the extreme distribution patterns. These are shown by the Alipore-A and -D and Dumdum-A and -D curves of Figure 8 for the worst extreme cumulative rainfall distribution curves that are advanced (A) or delayed (D) in time for these two stations. The hourly ordinates of the 2, 5 and 10 years of return period intermediate (I) hyetographs are rearranged for advanced and delayed peak distributions (indicated as $n$ yr-A/D in Figure 8 where $n$ is return period in years) such that their cumulative graphs match the observed extreme cumulative graphs of Alipore and Dumdum stations as closely as possible.
Application of the hypothetical rainfall hyetographs of different return periods and time distributions to the sewer-flow model generates the catchment outflows (that is, the discharges at the sewer network outlets) and surcharges from the sewers. The surface-inundation model computes the resulting inundation extents caused by the sewer surcharges. For brevity, only results obtained for the Town system - the oldest sewer network of the city - are presented and the results analysed.

Figure 9(a) compares the peak discharges reaching PBPS - the terminal pumping station of the Town catchment. As expected, these are seen to increase with rainfalls of higher intensities (greater return periods). The three distributions produce nearly the same peak discharges for the same rainfall, though the delayed distribution shows a greater rise with increasing return period than the other two. The lag time or time difference between the peaks of rainfall hyetograph and discharge hydrograph (Figure 9(b)) indicates that this parameter is significantly affected by the rainfall event's time distribution. The lag time is least for the delayed distribution, a woe for authorities concerned with mobilising relief, whereas Figure 9(c) shows the variations in inundated areas (depths greater than $0.8 \mathrm{~m}$ ) expressed as a percentage of the catchment area with rainfall intensity and distribution type. Increasing intensity causes greater inundations but with higher return periods, inundation does not increase much. This corroborates well with the general apprehension of flooding in the city that the water accumulates only in specific depression-like pockets in the otherwise flat terrain and does rarely spread farther away from these 'hotspots'. Similarly, rainfall time distribution does not seem to affect much though the advanced distribution generates greater flooding extents in each case.

\subsection{Conduit wall roughness}

The sewer conduits are lined with GRP, for which the Manning's roughness coefficient $\left(n_{\text {conduit }}\right)$ is taken as 0.01 , as obtained through calibration and also indicated in the industry guides of GRP pipe manufacturers. However, with use, the surfaces of the linings are likely to get abraded and roughen and three roughness values for the conduits ( $n$ conduit $=0.01,0.02$, and 0.04$)$ are examined. Results for only one rainfall return period (2-year) are presented as they are similar for other intensities of storms.

Figure 10(a) presents the peak discharges reaching the PBPS for varying conduit roughness and storm types. As 


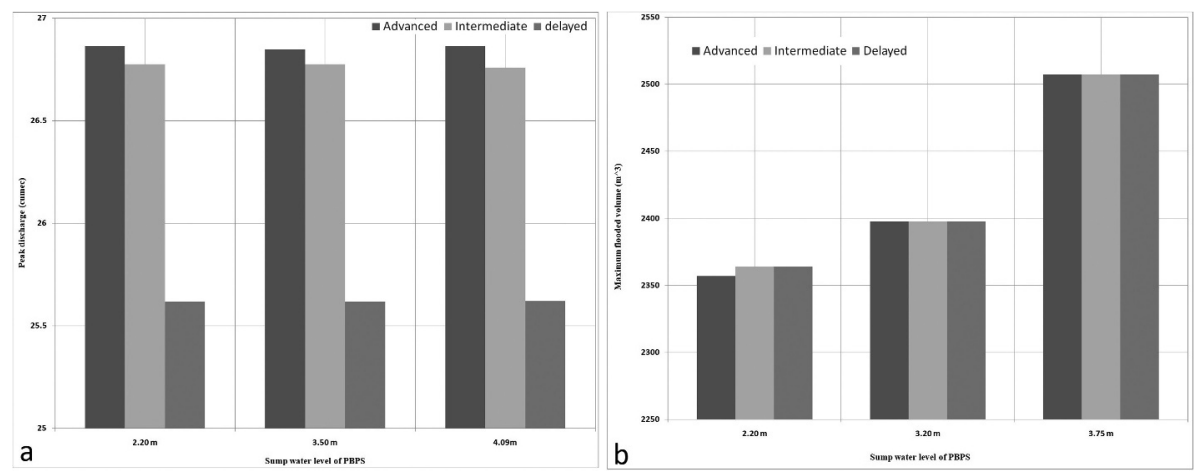

Figure 11. Peak discharge (a) and maximum flooded volume (b) for three different sump water levels of PBPS.

expected, increasing friction slows down the flows in conduits, resulting in a moderation of the peak. There does not appear to be much difference in the flows due to the time distribution of the storms. Figure 10(b) shows the maximum volume of water expelled to the streets from the surcharge computed for one computational time step. For low conduit friction, the delayed pattern significantly affects the peak of surcharged volumes. The advanced rainfall peak consistently shows lower surcharges for all friction values while the delayed pattern shows the greatest surcharge among all three for $n_{\text {conduit }}=0.01$. For rougher conduits, the intermediate and delayed rainfalls expel nearly similar volumes.

\subsection{Sump water level and ground surface roughness}

High-capacity pumps, each of 240 cusec $\left(\sim 6.8 \mathrm{~m}^{3} \mathrm{~s}^{-1}\right)$ discharge capacity, have recently been installed at the pumping stations, replacing the older pumps of smaller capacities that had been running for the past few decades. These pumps have helped in clearing the water reaching the sumps rapidly. The influence of the sump water level, which varies between around $2.20 \mathrm{~m}$ and $3.75 \mathrm{~m}$ (above Mean Sea level) for PBPS, is shown in Figure 11, where the peak discharge and maximum flood volume from three discrete sump levels have been compared, respectively (11a and 11b). The computed peak discharges for different sump water levels and rainfall patterns indicate that the level does not affect the flows much. This suggests that the sump has been located at a level much below that of the conduits and a large variation in its water level does not affect the flows in the conduits by backflow, which may be considered as a good design aspect.

The roughness of the ground surface $\left(n_{\text {surface }}\right)$, specified in LISFLOOD-FP for simulating surface inundation, is varied between 0.04 and 0.08 as recommended in texts like ARR (2012), and simulations are carried out for the three rainfall types of 2, 5 and 10 years of return periods. However, no significant change in the inundation extent or duration is observed. A reason for this is the extremely flat terrain of the city, whose average slope is of the order of $0.01 \%$. Largely, overflowing water from surcharged sewers fill pockets of low depression and return back to the sewers on the easing of pressured conditions. As observed, there is hardly any observable flow velocity on the ground during the flooding events. A variation in friction coefficient, therefore, does not make much difference to the spatial distribution of the flooded areas.

\section{Conclusions}

The three combined sewer and drainage networks of Kolkata, the initial laying of which commenced more than 150 years ago, are evaluated in this study for sewer overflowing and overland flooding using mathematical models. Probable conditions are tested to check their adequacy under increasing urban pressures. The following conclusions are inferred from the study:

1.Keeping pace with urbanisation, both base flows and storm runoffs have increased for the sewers. The former has been due to an increase in population, resulting in an increase of wastewater flows, while the latter has been due to a rise in the proportion of paved area within the sewercatchments.

2.Though the main conduits of the sewer networks have recently been lined for reducing flow friction, and highcapacity pumps installed at the terminal pumping stations for faster evacuation of the accumulating water in the sumps, the extent of street flooding has not mitigated enough as was perhaps expected. A reason behind this is found to be the inadequacy of the conveyance capacities of the conduits. Possibly, if the sizes of the conduits were increased while the lining work was in progress, the extent and depths of flooding might have reduced. However, the residence time of the overflowing surcharge volumes has reduced, apparently due to the smoother conduits and higher pumping rates.

3.Rainfall events of different intensities and time-distributions, derived from a 30-year record of hourly rainfall data indicate that (i) the peak discharge reaching the pumping stations increases marginally with rainfall intensity and are nearly the same for the three types of rainfall distribution patterns for a given rainfall intensity; (ii) the surface-inundation extent is nearly the same for the 5- and 10-year return periods but much less for the 2-year return period rainfall; (iii) the lag-time is minimum for the delayed rainfall pattern for any given rainfall intensity.

4.Increasing roughness of the conduits (as with aging) reduces the peak discharge reaching the pumping stations but results in expelling an increasing volume of water on to the streets during a rainfall event. However, the pattern of the storm does not cause much difference to these parameters.

5.The sump water level does not significantly influence the peak discharge of the sewer outfall at the pumping station, but higher sump levels seem to force a larger flooding volume as surcharges through the manholes.

6.The pumps located at the terminal ends of the sewer networks lift the water accumulating in the sumps by a few 
meters and discharge into drainage channels. However, though the tail end of the $35 \mathrm{~km}$ long channel is tide-dominated, pumping is rarely affected by tidal influences except during rare coincidental occurrences of high rainfall and high tides as it happened in 1978 or 2000 .

\section{Acknowledgments}

The authors wish to acknowledge and thank the computer company IBM for financial support through their Centennial Grants project that aided in the installation of sensors in Kolkata at the initial stages and to conduct a DEM survey; Kolkata Municipal Corporation (KMC) for providing the rainfall and sump water level data. The authors also offer special thanks to Prof. Paul Bates of the School of Geographical Sciences, University of Bristol, UK for providing access to LISFLOODFP code. The India Meteorological Department (IMD) is thanked for the historic hourly rainfall data.

\section{Disclosure statement}

No potential conflict of interest was reported by the authors.

\section{ORCID}

Nazimul Islam (D) http://orcid.org/0000-0002-5295-3773

\section{References}

ARR. (2012). "Two-dimensional modelling in urban and rural floodplains". Australian Rainfall \& Runoff Project 15. Institution of Engineers, Australia.

Basu, N.B., Boral, S., Mandal, S.K., and Dey, A. (2013a). "Rehabilitation of Kolkata's first Victorian-age brick sewer." Proc. Instit. Civil Eng. Muni. Eng., 166(4), 230-238. doi:10.1680/muen.12.00051.

Basu, N.B., Boral, S., Mondal, S.K., and Dey, A. (2014). "Trenchless refurbishment of a Victorian-age brick sewer in Kolkata." J. - Am. Water Works Associat., 106(5), 76-85. doi:10.5942/ jawwa.2014.106.0071.

Basu, N.B., Dey, A., and Ghosh, D. (2013b). "Kolkata's brick sewer renewal: History, challenges and benefits." Proc. Institu. Civil Eng. Civil Eng., 166(2), 74-81. doi:10.1680/cien.12.00016.

Bates, P.D., and De Roo, A.P.J. (2000). "A simple raster-based model for flood inundation simulation.” J. Hydrol., 236(1-2), 54-77. doi:10.1016/S0022-1694(00)00278-X.

Bhatta, B. (2009). "Analysis of urban growth pattern using remote sensing and GIS: A case study of Kolkata." Indian Int. J. Remote Sen., 18(18), 4733-4746. doi:10.1080/01431160802651967.

Bose, P.C. (1944). "Calcutta sewage-fisheries culture." Proc. Nat. Instit. Sci. India, 10(4), 443-454.

Census India (2011) Census of India. <http://censusindia.gov.in> (Accessed October 2020).
Chow, V.T., Maidment, D.R., and Mays, L.W. (1988). Applied hydrology. McGraw, Singapore. reprinted in 2016 by McGraw Hill Education Pvt. Ltd. New Delhi, India.

Dasgupta, D. (2019). "East Kolkata wetlands: Integrating sanitation, engineering and ecology." Proc. Instit. Civil Eng.- Eng. History Heritage. doi:10.1680/jenhh.19.00018.

Dey, A. (2015). "Calcutta's sanitation heritage: A unique engineering legacy." Proc. Institut. Civil Eng. - Eng. History Heritage, 168(3), 101112. doi:10.1680/ehah.14.00006.

Dey, A., and Downey, D.B. (2020). "Victorian brick sewers for a clean flowing Indian colonial city." Proc. Institution of Civil Engineers - Eng. History Heritage, 173(4), 131-145. doi:doi:10.1680/jenhh.19.00012

Gangopadhyay, A., and Patra, P. (2019). "The historical background of the canal system in Calcutta, India, and its contribution to development." Proc. Instit. Civil Eng. Themed Issue Calcutta: Part I, Eng. History Heritage, 173(3), 80-91. doi:10.1680/jenhh.19.00024.

Gardner., R.M.J., Sanyal, T., Gangopadhyay, A., and Dey, A. (2020). "Calcutta Port: India's first port facility nears 150 years of operation." Proc. Instit. Civil Eng.- Themed Issue Calcutta: Part I, Eng. History Heritage, 173(3), 104-116. doi:10.1680/jenhh.19.00028.

Ghosh, D., and Sen, S. (1987). "Ecological history of Calcutta's wetland conversion.” Environ. Conserv., 14(3), 219-226. doi:10.1017/ S0376892900016416.

Goode, S.W. (1916). "Municipal Calcutta: Its institutions in their growth and origin." TઐA Constable, Edinburgh, UK. reprinted in 2005 by Kolkata Municipal Corporation and McMillan, New Delhi, India.

Haque, S.M. (2013). "Urban expansion around metropolitan core and its impact on land use changes: A geo-spatial analysis." Unpublished $\mathrm{PhD}$ Thesis, University of Calcutta, India.

Hettiarachchi, M., Morrison, T.H., and McAlpine, C. (2015). "Fortythree years of Ramsar and urban wetlands." Global Environ. Change, 32, 57-66. doi:10.1016/j.gloenvcha.2015.02.009.

Mukherjee, S., Bebermeier, W., and Schutt, B. (2018). "An overview of the impacts of land use land cover changes (1980-2014) on urban water security of Kolkata." Land, 91(7), 1-25. doi:10.3390/ land7030091.

Rossman, L. (2015). "Storm water management model, EPA: User's manual Version 5.1.." National Risk Management Laboratory Office of Research and Development U.S. Environmental Protection Agency 26, Martin Luther King Drive Cincinnati, USA.

Saha, S., Saha, T., and Basu, P. (2016). "Planktons in dirty water: Carbon cycling process of sewage fed fisheries in East Kolkata Wetland, India." Wetlands, 36, 415-429. doi:10.1007/s13157-016-0750-y.

Sarkar, S., Ghosh, P.B., Mukherjee, K., Sil, A.K., and Saha, T. (2009). "Sewage treatment in a single pond system at East Kolkata Wetland, India." Water Sci. Technol., 60(9), 2309-2317. doi:10.2166/ wst.2009.673.

Sen, D. (2013). "Real-time rainfall monitoring and flood inundation forecasting for the city of Kolkata." ISH Journal of Hydraulic Engineering, 19(2), 137-144. doi:10.1080/09715010.2013.787718

Smith, D.B. (1869). Report on the drainage and conservancy of Calcutta. Bengal Secretariat Press, Kolkata, India.

World Bank. (2001). Project preparation studies for Calcutta water supply, sewerage and drainage projects. World Bank Project number PO 50648, draft final report prepared by Weston International, STUP Consultants Ltd., Metcalf \& Eddy, and Philadelphia Suburban Water Co. 